\title{
Analyzing Alternative Food Networks sustainability in Italy: a proposal for an assessment framework
}

\author{
Luigi Mastronardi ${ }^{1}$, Davide Marino ${ }^{2}$, Vincenzo Giaccio ${ }^{1}$, Agostino Giannelli ${ }^{1}$, Margherita Palmieri ${ }^{2}$ and \\ Giampiero Mazzocchi ${ }^{2,3^{*}}$ (D)
}

\author{
*Correspondence: gia.mazzocchi@ \\ gmail.com \\ ${ }^{2}$ Department of Biosciences and \\ Territory, University of Molise, \\ Contrada Fonte Lappone 8, 86090 \\ Pesche, Italy \\ ${ }^{3}$ Rome, Italy \\ Full list of author information is \\ available at the end of the article
}

\begin{abstract}
The aim of the paper is to evaluate the sustainability of Alternative Food Networks in Italy through the construction of a composite indicator, the Global Sustainability Index. The index is able to provide decision-makers with indications on synergies and tradeoffs between the different dimensions of sustainability. The methodological approach is of the quantitative type, and the information used in the study comes from a direct survey that involved 226 producers. The results show that the environmental indicators that take the greatest value are those concerning problems of great impact on the actual debate such as the loss of genetic diversity and the use of packaging for agro-food products. Regarding economic sustainability, the indicator with the highest value is related to the ability of the Alternative Food Networks to diversify sales channels. This evidence confirms the producers' increasing difficulty to adopt mono-directional strategies, favoring a differentiation of markets and, consequently, a reduction of economic risks. In terms of social sustainability, two interesting evidences emerge: the considerable importance attributed to the information of the features of the products and the increase in work involvement following participation in the Alternative Food Networks.

Keywords: Alternative Food Networks, Sustainability, Index, Short food supply chain, Producers, Food policies, Italy
\end{abstract}

\section{Introduction}

The study proposes a reflection on the sustainability of Alternative Food Networks (AFN). AFN were so named following the refusal of some food chain players to accept and adopt the defining elements of traditional supply chains, such as excessive productivity, standardization, and industrial organization (Higgings et al. 2008; Watts et al., 2005), placing instead a greater emphasis on other aspects, such as quality, origin, and the "naturality" of agro-food production (Renting et al. 2003).

Practices related to the sale of agro-food products through AFN have become widespread in recent years (Duncan and Pascucci, 2017). This evolution has affected both supply and demand: on the one hand, a large part of consumers is increasingly interested in "geographicised" food production; on the other hand, the producers are finding in these forms of direct marketing the possibilities linked to the economic sphere

(c) The Author(s). 2019 Open Access This article is distributed under the terms of the Creative Commons Attribution 4.0 International License (http://creativecommons.org/licenses/by/4.0/), which permits unrestricted use, distribution, and reproduction in any medium, provided you give appropriate credit to the original author(s) and the source, provide a link to the Creative Commons license, and indicate if changes were made. 
as for the socio-relational sphere (Dansero and Puttilli, 2014). In fact, the reduction of the number of intermediaries between the production phase and the purchase phase by the final consumer allows to retain a greater share of the added value of the product, increasing the profit margins and thus allowing to remunerate adequately the factors of the production (Kneafsey et al., 2013). Moreover, the direct relationship with the final consumer allows the producer to interpret the evolutions and needs of the food demand and, at the same time, to communicate in a more effective way the strengths and the qualitative aspects of the farm, creating very often the fertile ground for a mutual increase in trust and for a loyalty between seller and buyer (Marino et al., 2018). The innovations related to AFN do not concern only the marketing phase of the product. Indeed, AFN present interesting new elements, since they are configured as parallel to conventional food supply chains and represent alternative methods of production, distribution, retail, and final purchase (Galli and Brunori, 2013). "Alternativity" takes into account sustainability in its triple economic, environmental, and social meaning. In this context, AFN respect the three dimensions that define their "alternativity" (Whatmore et al. 2003): (1) to function as food markets that distribute the value through the network against the logic of mass production, (2) to contribute to the reconstruction of "trust" between food producers and consumers, and (3) to design new forms of social association and market governance.

The absence-or the reduced number-of intermediaries between producer and consumer characterizes the AFN compared to the conventional one (Barbera and Dagnes, 2016). Often, this organizational-logistical proximity is accompanied by a spatialgeographical proximity, but it is not possible to state that it is the totality of the cases. In this regard, there are various definitions of AFN: for example, in France, according to the classification adopted by the Ministry of Agriculture (Barry, 2012), the AFN refer to the marketing of agricultural products through direct or indirect mediate sales, at most, from an intermediary. This definition meets the statement by Peters (2012) according to which the AFN are not only focused on the geographical distance between production and sales of the product, but also by the number of connections in the food chain. In Italy, there is currently no national definition of an AFN, although some regions have regulations for their classification and promotion, according to environmental or territorial criteria, depending on the case. In any case, the AFN find space mainly in urban areas: as a result, it is possible to state how, although it is not possible to coincide a priori AFN with the "zero kilometer," there is certainly a strong territorial connotation (Cavallo et al., 2015).

In the short chains, the issue of access to food is therefore linked in an innovative way to the sustainability of local food systems (Mastronardi et al. 2015). In relation to this, the role of the agricultural enterprise, with its strategies and related innovation processes, remains central in the training processes of the AFN (Ilbery, Maye, 2005; Giarè, Giuca, 2012). In fact, farms operating within urban and peri-urban areas often adopt diversification processes and differentiation strategies (Marino et al., 2018; Torquati et al., 2009) in which the shortening of the supply chain is one of the most frequent and of greater success (Henke, Vanni, 2017) that often accompanies other types of innovation (Diamantini, 2016).

Most of the studies on the sustainability of AFN have focused on specific aspects of sustainability-economic, environmental, or social, depending on the case (Penker, 2006, 
Wiese et al., 2012, 2015, Mastronardi et al., 2015). Other studies have been conducted on the sustainability of AFN compared to traditional supply chains (Brunori et al., 2016; Fabbrizzi et al., 2014; Holloway et al., 2007) and on the contribution to the sustainability of specific productions by producers belonging to French AFN (Enjolras and Aubert, 2018). However, even with a view to a scientific response compared to what Born and Purcell (2006) define as "local trap"-the assumption that eating local food is more sustainable-the contribution of the various forms of AFN to sustainability has not yet been clarified (Tregear, 2011; Venn et al., 2006). The construction of a framework for the assessment of sustainability of AFN aims exactly at providing a solid base for understanding the real contribute of alternative channels of sales to the main environmental, social, and economic challenges. We consider it necessary to shed a light on the debate on the local trap and the tendency of food activists and researchers to assume something inherent about the local scale. The local is assumed to be desirable; it is preferred a priori to larger scales (Born and Purcell, 2006).

In this scenario, the aim of the work is to evaluate the sustainability of Alternative Food Networks in Italy through the construction of a composite indicator based on the indicators mostly used in studies on the sustainability of food systems (FAO, 2014, Barilla, 2014, GRI, 2011; Cicatiello and Franco, 2012; UN DPSCD, 1996; Zezza, 2013). In relation to this, the paper aims to identify the contribution of these marketing channels in representing and disseminating the principles of sustainability, to outline a scenario in which to define regulatory actions that can regulate and promote these complex realities. Through a Global Sustainability Index that represents a specifically built synthetic index, it has been possible to assess different AFN experiences. Finally, the paper aims to compare the different sustainability performances of the producers participating in the various Alternative Food Networks schemes, in order to identify the elements that characterize them and to provide evidences for a better implementation of urban food policies.

\section{Methodology}

\section{Materials}

The methodological system is of the quantitative type, and it is aimed at the construction of a summary index to assess the sustainability of farms participating in the various short food supply chain schemes and, at the same time, to provide decision-makers with indications on synergies and trade-offs between the different dimensions of sustainability. The information used in the study comes from a direct survey that involved 226 producers selling in AFN of five Italian cities (Trento, Torino, Pisa, Roma, and Lecce), selected on the basis of territorial distribution and market scheme: farmer markets, solidarity purchasing group, farms selling directly, box schemes, community-supported agriculture, and farms that sell simultaneously through various AFN. The five case studies analyzed are located in different areas of Italy and present non-uniform characteristics. This aspect has allowed us to analyze a wide range of very different experiences. In all territorial contexts, an urban center was taken as a reference, analyzing food short chain experiences that in various ways gravitated towards this center. Two focus groups were employed to identify the territorial cases (cities), types of AFN and farms, the first involving the supply chain stakeholders and the second scholars and academics. The sampling was random, and the survey was conducted using structured 
questionnaires to producers selling in AFN, so the evaluation of the AFN's sustainability is based mostly on their attitude towards sustainability. The objectives of the survey led to articulate the sections of the questionnaire according to the following sections:

1. A first series of questions regarding the history and motivations that link the producer to the AFN experience in relation to which he was interviewed

2. A second series of questions related to his perception of the environmental, social, and economic implications of his participation in that AFN experience

3. A final section dedicated to an in-depth examination of the farm profile, in which information on the producer and farm structure were requested

Variables were conceived on a Likert scale with 5 points (from 1 to 5 ): the producers had to give a sort of "vote of appreciation" for each question included in the questionnaire.

\section{The Global Sustainability Index and the assessment framework}

The construction of the Global Sustainability Index (GSI) has been retained useful as to evaluate the sustainability performance of AFN from a systemic perspective. Indeed, AFN have often been evaluated for their contribution to social reconnection of consumers and producers and for their capacity to be a lever for local development (Gaviglio et al., 2016; Blasi et al., 2015); in other cases, studies have been conducted on some specific agro-food products or supply chain (Galli et al., 2015); finally, other researches about the correlation between local food chains and sustainability have been conducted (Brunori et al., 2016), but quantitative results are missing. Through the GSI, our aim is to assess the performances of three pillars of sustainability (environmental, economic, and social), independently of the product or supply chain. Moreover, the GSI allows to obtain a synthetic index that immediately reflect the three levels of sustainability for AFNs' farms and producers, offering a quantitative and reliable output.

The methodology used for the construction of the indexes is divided into two phases: (1) construction of the GSI and (2) application of multivariate statistical analysis methodologies.

The GSI has been built merging simple indicators deriving from the survey mentioned above and the indicators of SAFA (Sustainability Assessment of Food and Agriculture Systems), an internationally recognized holistic global framework for the assessment of sustainability along food and agriculture value chains. SAFA establishes an international reference for assessing trade-offs and synergies between all dimensions of sustainability (FAO, 2014). It has been prepared by so that enterprises, whether companies or small-scale producers, involved with the production, processing, distribution, and marketing of goods, have a clear understanding of the constituent components of sustainability and how strength, weakness, and progress could be tackled. The SAFA framework is composed by 21 core sustainability issues (themes), detailed into 58 individual issues (sub-themes) with associated explicit sustainability objectives. Furthermore, SAFA has defined default 116 indicators within each sub-theme which identify the measurable criteria for sustainable performance for the sub-theme. For this reason, considering the completeness of the framework and its international usage, it has been considered that SAFA represents a tool that, if properly adapted, can constitute a sound 
base for the construction of a set of indicators capable to assess the sustainability of the different experiences of AFN recorded by the survey. Particularly, the structure of the framework has been maintained and the indicators that are more adapt to assess AFN have been chosen.

The construction of the GSI took place through the selection of indicators starting from the SAFA Guidelines. The framework for AFN sustainability assessment reflects the SAFA structure and sustainability philosophy: indeed, it is composed by a "cascade" scheme composed of pillars (4), themes (17), sub-themes (28), targets (32), and indicators (36) (see Additional file 1 for the complete list of themes, sub-themes, targets, and indicators). Nonetheless, in the literature exist several categorizations of sustainability pillars in the context of food chains (Watts, 2005; Gibson, 2006; Lamine, 2014); in order to assure coherence with the SAFA framework, it has been chosen to maintain the same classification.

Regarding the choice of the indicators, starting from the SAFA guidelines, the most appropriate indicators deriving from the original survey have been selected to describe the sustainability of farms belonging to AFN, taking into account their main features, as described in the "Introduction" section. All the indicators relating to other kinds of companies in the agro-food supply chain (fisheries sector, forest sector, distribution and/or processing companies) have been excluded. The same choice has been made in the cases they are applicable only to large companies that are very well structured from an administrative point of view. The evaluation framework of the AFN farms, built on the basis of the SAFA document, with the appropriate indicators that explain the related targets, is described here below:

- Four sustainability pillars: environment, economy, society, and governance

- Seventeen themes: atmosphere, water, land, biodiversity, materials and energy, investment, vulnerability, production quality and information, local economy, decent livelihood, equity, human safety and health, cultural diversity, corporate ethics, accountability, participation, rule of law

- Twenty-eight sub-themes: air quality, water withdrawal, soil quality, land degradation, genetic diversity, ecosystem biodiversity, material use, waste reduction and disposal, community investment, profitability, stability of production, liquidity, value creation, quality of life, community investment, stability of market, product information, value creation, gender equality, support to vulnerable people, non discrimination, public Health, food sovereignty, indigenous knowledge, due diligence, transparency, stakeholder dialogue, conflict resolution, civic responsibility, resource appropriation

- Thirty-two targets: see Additional file 1 for the complete list

- Thirty-six indicators: see Additional file 1 for the complete list

It is worth to point out that 10 out of the 36 indicators of the GSI were not available in respect to the original structure and contents of the survey. For this reason, Table 1 contains the indicators that were available and on which the results are based on.

\section{The multivariate statistical analysis methodologies}

After the construction of the Global Sustainability Index, the following steps were necessary in order to make possible the multivariate statistical analysis methodology: 
Table 1 List of the available indicators starting from the complete list of the Global Sustainability Index

\begin{tabular}{|c|c|c|}
\hline Pillars & Indicators & Code \\
\hline \multirow[t]{10}{*}{ Environment } & Reduction of the distance travelled by the products & N1 \\
\hline & Organic UAA & $\mathrm{N} 2$ \\
\hline & Changes in farming choices & N3 \\
\hline & Woodland & \\
\hline & Meadows and pastures & \\
\hline & Sale of products from traditional and local agricultural varieties or animal breeds & N4 \\
\hline & UAA falling into protected areas & N5 \\
\hline & UAA Equipartition & \\
\hline & Greater attention to the consumption of resources used in the farm & N6 \\
\hline & Sale of products without packaging & N7 \\
\hline \multirow[t]{7}{*}{ Economy } & Birth of a personal relationship with consumers & E1 \\
\hline & Agro-tourism with restaurant & E2 \\
\hline & Improvement of the farms growth prospects & E3 \\
\hline & Diversification of sales channels & E4 \\
\hline & Higher prices in respect to other sales channels & E5 \\
\hline & Intensification of connections with the local economy & E6 \\
\hline & Increase in business income & E7 \\
\hline \multirow[t]{8}{*}{ Society } & Agro-tourism with educational farm/recreational activities & S1 \\
\hline & Sale of farm's products to the local community & S2 \\
\hline & Inform consumers about the nutritional value of products & S3 \\
\hline & Greater work commitment following participation in the AFN & S4 \\
\hline & Women workers & S5 \\
\hline & Young workers & S6 \\
\hline & Disabled workers & \\
\hline & Cultural activities & S7 \\
\hline
\end{tabular}

a) Standardization of indicators to purify them from different units of measurement.

b) Choice of the functional form of the index, of the type:

$$
I S(\ldots)=\sum_{i}^{k} w_{i} I_{i}, \mathrm{i}=1,2, \ldots \mathrm{k}
$$

where SI (...) is the Sustainability Index relative to the generic domain (...) with $k$ indicators $I_{\mathrm{i}}$ and $w_{\mathrm{i}}$ is the relative weight assigned to the $i$-th indicator, so that SI (..) $\varepsilon[0,1]$.

c) Hierarchization of indicators. The weights $w_{\mathrm{i}}$ were assigned according to a mathematical procedure that took into account the relative importance of the selected indicators in the $k$-dimensional vector space, in which each indicator is a vector of length $n$ consisting of the $n$ farms included in the sample. The variability observed in the matrix $(n \times k)$ was reduced by PCA to a number of dimensions $v<k$ represented by the main components $\lambda 1, \lambda 2, \ldots, \lambda v$ each of which is a linear combination of the starting $k$ variables (aliases). In this way, a vector $w_{1}, \ldots . w_{\mathrm{k}}$ of distinct weights was obtained for each set of indicators N1, ... N7; E1, ...., E7; S1, ...., S7. 
d) Calculation of the Global Sustainability Index which derives from an arithmetic average of the environmental, economic, and social sustainability indexes, also proposed in a weighted form if it is desired to assign a greater incidence to one of the three domains. The weight is here assigned in discretionary form to provide space for different ways of interpreting the final value.

$$
\mathrm{GSI}=W \mathrm{env} * \mathrm{SIenv}+W \mathrm{eco} * \operatorname{SIeco}+W \operatorname{soc} * \operatorname{SIsoc}
$$

where $W(\ldots)$ is the relative importance [from 0 to 1 ] that the decision-maker assigns to the reference domain.

A comparison was made of the average values of the indicators by domain and type of AFN (farmers' market, FMs; solidarity purchase group, SPG; direct sales, DS; other types, OTHER). The choice of comparing the indicators rather than the sustainability indices by type of supply chain derives from the method adopted for the calculation of the SI: segmenting the sample by supply chains, the vector of the generated $w_{\mathrm{i}}$ for each group varies according to the variability within each group and can significantly influence the final value. The direct comparison of the indicators is independent of the hierarchy procedure and offers much more detailed information than the summary indexes. The differences observed in the mean values of each indicator were statistically tested using mono and multivariate variance analysis. In particular, the MANOVA test was applied preliminarily to all groups in order to verify if there is at least one pair of groups for which at least one indicator has statistically different mean values between the two groups, assuming as acceptance threshold a $p$ value less than 0.05 (Wilk's lambda test and Pillai trace). If so, the test identifies for which pairs exist significant differences between indicators. With regard to the only pairs identified by the previous test, the ANOVA analysis by single indicator allows to calculate the values of $F$ and $p$ assuming the following parameters as significance level: $\left(^{* * * *}\right) p<0.001$; $(* *) 0.001<p<0.01 ;(*) 0.01<p<0.05$.

\section{Results and discussion}

The results are analyzed and discussed in this section. In particular, in the first part, the values of economic, social, and environmental sustainability are reported and analyzed at the level of the entire survey sample. Subsequently, the various short supply chain schemes have been compared to obtain the result of their contribution to the three domains of sustainability.

Table 2 shows the values of the environmental sustainability (IS_ENV), economic (IS_ECO), and social (IS_SOC) indices calculated according to the methodology illustrated in the previous paragraph. For each indicator, the weight, the average value in the sample, and the contribution (value $=$ weight $\times$ average) are reported to the formation of the final value expressed by the indices.

The value of the Global Sustainability Index for the system of the AFN as a whole is equal to the weighted arithmetic average of the three indices, which in the case of homogeneous weighting $\left(W_{\text {env }}=W_{\text {eco }}=W_{\text {soc }}=1\right)$ assumes a value equal to 0.543 .

Only by way of example, in the case of a non-homogeneous weighting system, applying to equation at the matrix: 
Table 2 Values of sustainability indices

\begin{tabular}{clllllllllll}
\hline ENV & Weight & Average & Value & ECO & Weight & Average & Value & SOC & Weight & Average & Value \\
\hline N1 & 0.041 & 0.138 & 0.006 & E1 & 0.065 & 0.904 & 0.059 & S1 & 0.250 & 0.142 & 0.035 \\
N2 & 0.019 & 0.036 & 0.001 & E2 & 0.158 & 0.088 & 0.014 & S2 & 0.084 & 0.868 & 0.073 \\
N3 & 0.054 & 0.172 & 0.009 & E3 & 0.094 & 0.769 & 0.073 & S3 & 0.131 & 0.794 & 0.104 \\
N4 & 0.278 & 0.800 & 0.223 & E4 & 0.185 & 0.665 & 0.123 & S4 & 0.152 & 0.768 & 0.117 \\
N5 & 0.020 & 0.032 & 0.001 & E5 & 0.138 & 0.627 & 0.087 & S5 & 0.188 & 0.261 & 0.049 \\
N6 & 0.276 & 0.655 & 0.180 & E6 & 0.111 & 0.667 & 0.074 & S6 & 0.033 & 0.311 & 0.010 \\
N7 & 0.313 & 0.688 & 0.215 & E7 & 0.118 & 0.689 & 0.082 & S7 & 0.161 & 0.058 & 0.009 \\
& & IS_ENV & 0.635 & & & IS_ECO & 0.596 & & & IS_SOC & 0.398 \\
\hline
\end{tabular}

$$
W=\begin{array}{lll}
2 & 1 & 1 \\
1 & 2 & 1 \\
1 & 1 & 2
\end{array}
$$

the following values for environmental-, economic-, or social-oriented GSI would be obtained:

$$
\mathrm{GSI}_{\mathrm{env}}=0.566, \mathrm{GSI}_{\mathrm{eco}}=0.556, \mathrm{GSI}_{\mathrm{soc}}=0.507
$$

With regard to the dimensions of sustainability, the values of the indicators show how farms are more sensitive to environmental and economic aspects, rather than to social ones. The producers recognize, in particular, a greater importance to the environmental dimension (0.635), while the economic aspect assumes a lower value (0.596).

The analysis of the contribution that each indicator contributes to sustainability highlights a rather interesting scenario.

In environmental terms, the N4 (Genetic Diversity) and N7 (Waste Reduction and Disposal) indicators get the highest score. Farms adhering to AFN in order to meet consumer demand for quality (Goodman, 2003) adopt more extensive agricultural techniques and offer a wide variety of products (Aguglia, 2009). This often results in the recovery of traditional varieties of vegetables, old fruit cultivars, or dairy products obtained from native breeds (Raffaelli et al., 2009). In this way, the sale of products deriving from traditional and local crops and breeds leads to an increase in genetic diversity, thanks to the supply of differentiated food compared to the standardization of conventional distribution chains. The location of these farms in areas characterized by great conservation potential of natural resources represents a great opportunity to guarantee their conservation against the risk of abandonment (Cicatiello and Franco, 2012). In this context, the potential of these farms to highlight the environmental quality of the areas in which they operate (Mastronardi and Giannelli, 2016) has clearly emerged. In the short chains, the reduction in the number of intermediaries in the supply chain brings with it the elimination of most of the waste and residues connected to the use of the packaging required by modern distribution (Aguglia, 2009). Also in this respect, therefore, the development of the AFN acts in the sense of greater environmental sustainability. With regard to the impact of the variables, quantitative ones (N2-Organic UAA; N3-Changes in farming choices, Woodland, Meadows and 
pastures; N5-UAA falling into protected areas; UAA Equipartition) have a lower weight compared to qualitative ones.

In economic terms, the E4 (Stability of Market) indicator has the greatest weight. AFN represent an important marketing channel for small businesses (Feenstra et al., 2002), sometimes even the only channel at their disposal (Brown, Miller, 2008), while medium-sized farmers use these markets to diversify sales channels thus reducing market risk. Farms use AFN to sell products to institutional consumers at times of the year when supply is excessive compared to demand (Hardesty, Leff, 2010), while continuing to use traditional marketing channels (Raffaelli et al., 2009). This strategy ensures the placement of the product avoiding the formation of surpluses, as well as the possibility of selling products at a higher price than the wholesale markets, while consumers can benefit from lower prices compared to retail (Tropp, 2008).

In social terms, the S3 (product information) and S4 (value creation) indicators have a greater impact. In the short food supply chain, producers communicate the specifications of their products, production systems, and the places where production takes place. In this way, producers offer the consumer information so that they perceive as a quality attribute the typicality and the particularity of the product they intend to buy (Aguglia, 2009). The communication of these aspects is not simple, but reduces the information asymmetry between producer and consumer. The correct information on the characteristics of the product means that its price is considered advantageous by the consumer, especially in the case of organic and biodynamic products (Marino, 2016). In this case, the role of AFN would become strategic, allowing in fact a more widespread access to this type of products, given the greater convenience compared to other forms of distribution (Sini 2009, Lyon et al., 2009). The short food supply chain, just because it affects all aspects of the global sustainability of the territory, can certainly be considered a useful tool for local development (Renting et al., 2003; Aubry et al., 2008). They represent a territorial and territorial presence, which produces significant impacts from the economic and social point of view and which is a function of the opportunities offered by these schemes in terms of access to the market, development of farm production, and use of family employment (Franco, Marino, 2012). With regard to the impact of the variables, quantitative ones (S5-women workers and S6-young workers, disabled workers) have a lower weight compared to qualitative ones.

Table 3 shows the results of the MANOVA test on the differences between the different supply chain schemes based on the three dimensions: environmental, economic, and social. The Wilks and Pillai tests have highlighted the existence of differences in the mean values for at least one pair of groups, assuming an acceptance threshold of the $p$ value $<0.05$. These values associated with each pair of groups are shown in the lower section of the table.

Table 4 shows the main descriptive statistics for the variables taken into consideration.

Table 5 shows the results of the ANOVA test in relation to the only statistically significant differences between the possible pairs of indicators.

\section{Environmental sustainability}

In environmental terms, ANOVA tests show a situation of low variability among almost all the markets surveyed. As a consequence, the various market schemes are fairly 


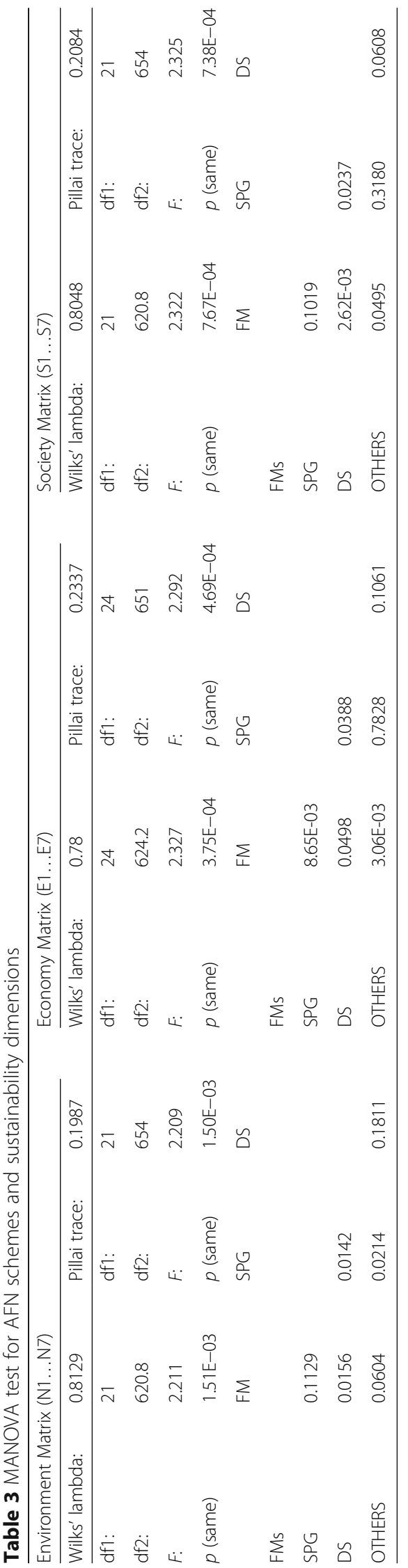


Table 4 Descriptive statistics of indicators by sustainability dimension and market scheme: $\mu=$ average, $M=$ median, $\sigma=$ standard deviation, $C . v$. = coefficient of variation

\begin{tabular}{|c|c|c|c|c|c|c|c|c|c|c|c|c|c|c|c|c|c|}
\hline \multirow[t]{2}{*}{ Dim } & & \multicolumn{4}{|l|}{ FMs } & \multicolumn{4}{|l|}{ SPG } & \multicolumn{4}{|l|}{ DS } & \multicolumn{4}{|c|}{ OTHERS } \\
\hline & & $\mu$ & $M$ & $\sigma$ & C.V. & $\mu$ & $M$ & $\sigma$ & C.V. & $\mu$ & M & $\sigma$ & C.V. & $\mu$ & $M$ & $\sigma$ & C.V. \\
\hline \multirow[t]{7}{*}{ Environment } & N1 & 0.14 & 0.08 & 0.16 & 1.13 & 0.19 & 0.17 & 0.24 & 1.26 & 0.09 & 0.06 & 0.10 & 1.08 & 0.09 & 0.04 & 0.11 & 1.22 \\
\hline & $\mathrm{N} 2$ & 0.03 & 0.00 & 0.10 & 3.95 & 0.06 & 0.01 & 0.16 & 2.69 & 0.05 & 0.01 & 0.14 & 2.71 & 0.04 & 0.01 & 0.07 & 1.69 \\
\hline & N3 & 0.17 & 0.17 & 0.14 & 0.84 & 0.14 & 0.13 & 0.14 & 0.98 & 0.21 & 0.17 & 0.12 & 0.57 & 0.19 & 0.17 & 0.16 & 0.82 \\
\hline & N4 & 0.79 & 1.00 & 0.28 & 0.35 & 0.80 & 1.00 & 0.30 & 0.37 & 0.91 & 1.00 & 0.19 & 0.21 & 0.69 & 0.80 & 0.31 & 0.45 \\
\hline & N5 & 0.02 & 0.00 & 0.08 & 4.31 & 0.01 & 0.00 & 0.05 & 4.08 & 0.09 & 0.00 & 0.21 & 2.44 & 0.08 & 0.00 & 0.17 & 2.02 \\
\hline & $\mathrm{N}$ & 0.65 & 0.60 & 0.27 & 0.41 & 0.64 & 0.80 & 0.29 & 0.46 & 0.75 & 0.80 & 0.24 & 0.32 & 0.55 & 0.60 & 0.34 & 0.61 \\
\hline & N7 & 0.72 & 0.80 & 0.31 & 0.43 & 0.57 & 0.60 & 0.32 & 0.57 & 0.70 & 0.80 & 0.30 & 0.42 & 0.68 & 0.80 & 0.33 & 0.48 \\
\hline \multirow[t]{7}{*}{ Economy } & E1 & 0.94 & 1.00 & 0.13 & 0.14 & 0.81 & 0.80 & 0.24 & 0.29 & 0.93 & 1.00 & 0.15 & 0.17 & 0.80 & 0.90 & 0.28 & 0.35 \\
\hline & E2 & 0.09 & 0.00 & 0.29 & 3.10 & 0.05 & 0.00 & 0.23 & 4.24 & 0.10 & 0.00 & 0.31 & 3.05 & 0.09 & 0.00 & 0.29 & 3.24 \\
\hline & E3 & 0.75 & 0.80 & 0.23 & 0.31 & 0.73 & 0.80 & 0.23 & 0.32 & 0.89 & 1.00 & 0.15 & 0.16 & 0.77 & 0.80 & 0.24 & 0.31 \\
\hline & E4 & 0.68 & 0.81 & 0.35 & 0.52 & 0.68 & 0.72 & 0.26 & 0.38 & 0.64 & 0.79 & 0.34 & 0.53 & 0.60 & 0.66 & 0.28 & 0.47 \\
\hline & E5 & 0.59 & 0.60 & 0.30 & 0.52 & 0.64 & 0.60 & 0.29 & 0.45 & 0.75 & 0.80 & 0.26 & 0.34 & 0.70 & 0.80 & 0.29 & 0.42 \\
\hline & E6 & 0.67 & 0.80 & 0.25 & 0.38 & 0.61 & 0.60 & 0.30 & 0.50 & 0.81 & 1.00 & 0.25 & 0.31 & 0.58 & 0.60 & 0.29 & 0.50 \\
\hline & E7 & 0.68 & 0.80 & 0.26 & 0.38 & 0.68 & 0.80 & 0.24 & 0.36 & 0.78 & 0.80 & 0.21 & 0.26 & 0.63 & 0.60 & 0.27 & 0.43 \\
\hline \multirow[t]{7}{*}{ Society } & S1 & 0.10 & 0.00 & 0.30 & 2.97 & 0.11 & 0.00 & 0.31 & 2.91 & 0.33 & 0.00 & 0.48 & 1.44 & 0.18 & 0.00 & 0.39 & 2.17 \\
\hline & S2 & 0.87 & 1.00 & 0.21 & 0.24 & 0.86 & 1.00 & 0.22 & 0.25 & 0.87 & 1.00 & 0.21 & 0.24 & 0.83 & 0.90 & 0.23 & 0.28 \\
\hline & S3 & 0.82 & 1.00 & 0.23 & 0.28 & 0.72 & 0.80 & 0.25 & 0.34 & 0.81 & 0.80 & 0.20 & 0.25 & 0.69 & 0.80 & 0.31 & 0.45 \\
\hline & S4 & 0.79 & 0.80 & 0.26 & 0.33 & 0.71 & 0.60 & 0.22 & 0.31 & 0.83 & 1.00 & 0.20 & 0.24 & 0.67 & 0.70 & 0.30 & 0.45 \\
\hline & S5 & 0.26 & 0.20 & 0.27 & 1.04 & 0.23 & 0.20 & 0.26 & 1.14 & 0.37 & 0.40 & 0.31 & 0.82 & 0.18 & 0.20 & 0.19 & 1.07 \\
\hline & S6 & 0.29 & 0.30 & 0.13 & 0.44 & 0.35 & 0.34 & 0.14 & 0.39 & 0.36 & 0.35 & 0.19 & 0.51 & 0.28 & 0.20 & 0.17 & 0.59 \\
\hline & S7 & 0.03 & 0.00 & 0.17 & 5.79 & 0.03 & 0.00 & 0.16 & 6.08 & 0.17 & 0.00 & 0.38 & 2.27 & 0.14 & 0.00 & 0.35 & 2.58 \\
\hline
\end{tabular}

homogeneous and they do not have significantly different mean values compared to the comparison between farmers that sell direct on one hand and those that sell using FM and SPG on the other. The farms that sell directly have higher values for the N4 (sale of products from traditional and local agricultural varieties or animal breeds) and N5 (UAA falling into protected areas + UAA Equipartition) indicators than for the FM ones and for the N3 (changes in farming choices/woodland/meadows and pastures) and N5 indicators compared to the farmers in the SPG group. For the N1 indicator (reduction of the distance travelled by the products), these present higher average values than the DS group and for the N5 indicator lower values than the farms of the OTHERS group. In FM, the greatest focus on the conservation of genetic resources may be due to the adoption of more sustainable production methods. In fact, in farmer markets, there is a greater share of products from organic or integrated agriculture compared to traditional markets (Mastronardi et al., 2015), due to consumer demand that focuses on quality products (Goodman, 2003). The interest in biodiversity is also due to the need to diversify production to meet consumer demand for variety. In relation to this, participation in FM allows farmers to regain control over their production decisions out of the vicious circle of squeeze on agriculture (van der Ploeg, 2009). For SPG farms, on the other hand, improving the quality of the air associated with reducing the distance travelled by food from the place of production to that of consumption is a very important aspect. SPG therefore have a positive influence in terms of reducing 


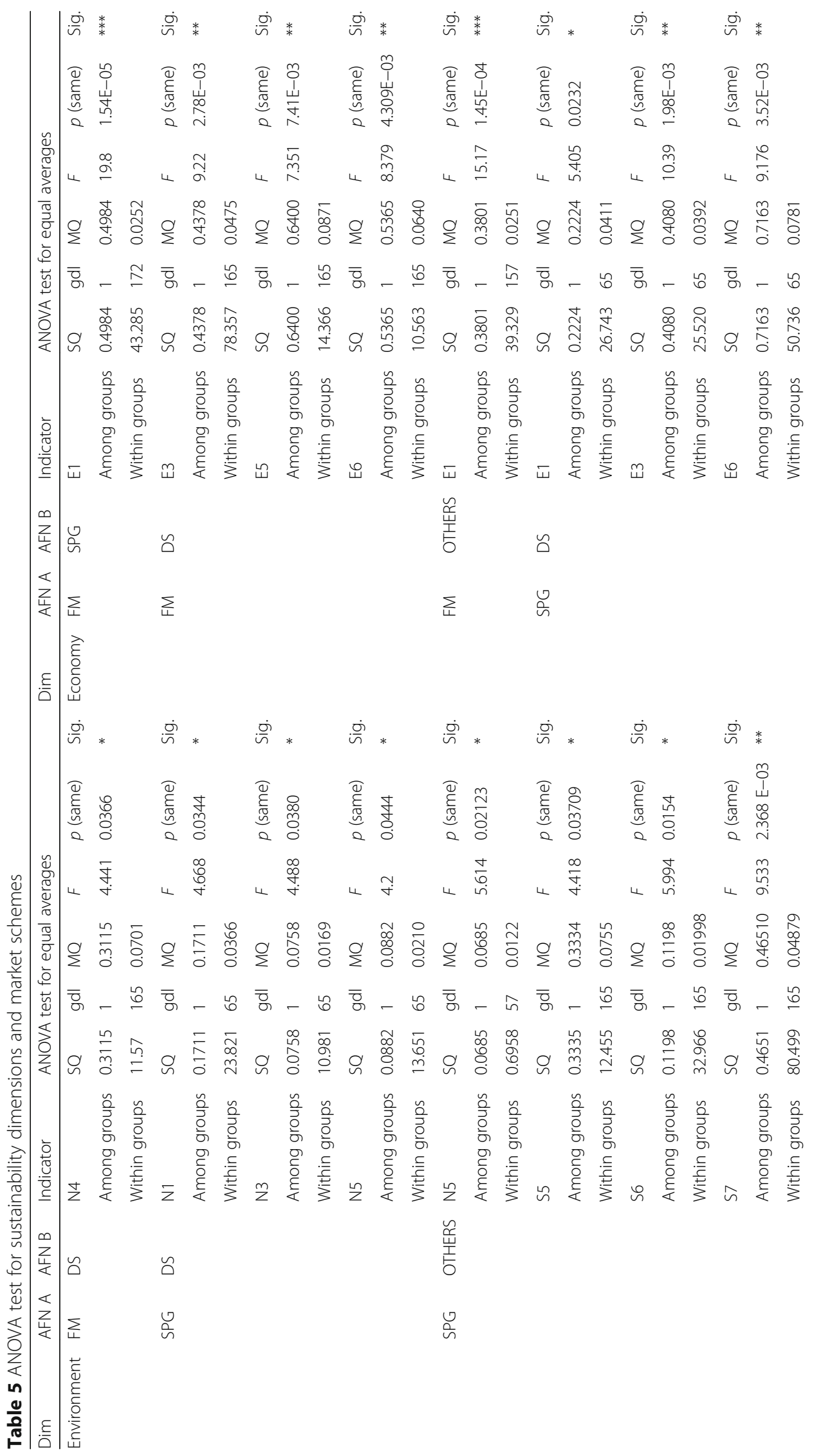




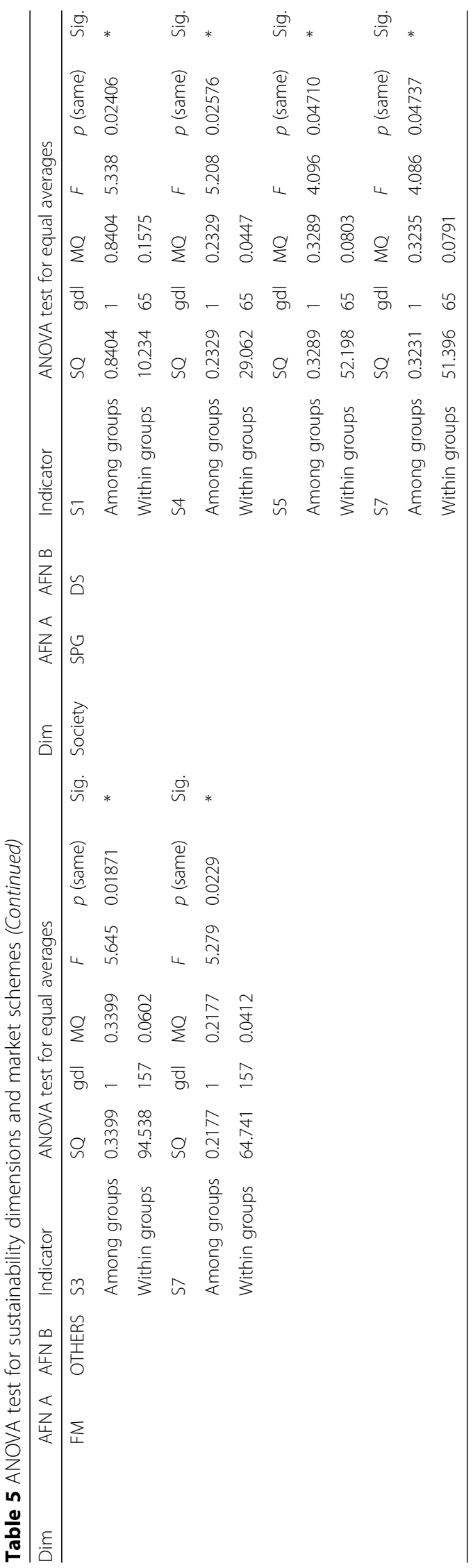


food miles: in this way, the negative externality connected to transport is limited: carbon dioxide emissions, air pollution and noise pollution, traffic, and accidents (DEFRA, 2005). The reduction of these externalities plays a key role in the assessment of global food sustainability (Sustain, 2002).

\section{Economic sustainability}

With regard to the economic dimension, the average values of the various market schemes are quite different for numerous indicators. The FM group associates values higher than the SPGs relatively to the E1 indicator (birth of a personal relationship with consumers). DS shows average values higher than FM relatively to indicators E3 (improvement of the farms' growth prospects), E5 (higher prices in respect to other sales channels) and E6 (intensification of connections with the local economy), and higher than SPG relatively to indicators E1 (birth of a personal relationship with consumers), E3 and E6. The FM farms show a clear focus on building a relationship between producers and consumers that re-establish relations with the territory and encourage investments that contribute to the sustainable development of the community. Producers who sell directly attribute greater importance to the stability of production which improves the farmer's growth prospects. Furthermore, for these producers, the AFN offers the opportunity to sell products at higher prices than other marketing channels and to obtain immediate financial benefits, i.e., continuous liquidity, as opposed to wholesale transfers where the payment is delayed over time. All this contributes to making the farm less vulnerable from an economic standpoint. Sales in the farm are the organizational form capable of having a wider impact on the local economy. The direct management at the farm headquarters of the marketing activities is able to significantly increase the profit margins on products, integrating the agricultural income with a constant flow of income. Direct selling is the market form most capable of reducing the output of monetary flows from the local system due to the purchase of goods produced elsewhere and allows farmers to intercept a greater share of added value. The economic advantage at the farm level also has a direct impact on the territory. This happens because a greater portion of added value is retained by the farmers, and indirectly because the value of the product translates into the value of the territory from which it comes (Ilbery and Maye, 2005), through the so-called multiplicative effect. Briefly, direct sales are seen by producers as attractive especially for profitability, ease of access, and the possibility of having immediate financial availability.

\section{Social sustainability}

In social terms, the differences in average values are mainly concentrated between the DS group on one side and FM and the SPG on the other. The DS group has higher averages than the FM for the S1 (agritourism with educational farm/recreational activities), S5 (women workers), S6 (young workers/disabled workers), and S7 (cultural activities) indicators. Likewise, the DSs have higher averages even than the SPGs for the S1, S4 (greater work commitment following participation in the AFN), S5, and S7 indicators. The FMs show higher average values for OTHERS for the S3 (inform consumers about the nutritional value of products) indicator, while the latter show higher values for the S7 indicator. In the direct sales group, activities that extend the spectrum 
of corporate functions beyond traditional ones (broadening functions), such as agro-tourism and cultural activities, are more frequent than other market schemes. This confirms a clear income integration strategy by diversifying processes and activities. Moreover, in the farms with direct selling, there is a particular spread of female employment and disabled workers. This market scheme is certainly more suitable to involve, from the employment point of view, the disadvantaged portions of the population, as the location of the sale in the farm structures, which typically represents the family residence, allows to engage in the activity commercial even those who can dedicate only part of the day to work (Cicatiello and Franco, 2012). The AFN has a positive effect on the reduction of information asymmetry and favors the spread of a territorial identity linked to food. Even farms classified as OTHERS provide cultural, educational, and demonstration activities related to food products.

\section{Conclusions}

Human decisions and choices (whether individual or collective) regarding production and consumption can influence food systems and improve their ability to deliver healthy and sustainable diets (HLPE, 2017). Though a radical transformation of the system linked to food production and consumption requires a huge effort at different scales (local, regional, and global) to redirect norms, behaviors (by producers and consumers), and governance objectives (Matacena, 2016). Moreover, current EU agro-food policies are not sustainable: on all three counts, economic, social, and environmental, the current trends are going in the wrong direction (IPES-Food, 2019). Historically, the EU opted for an approach seeking to guarantee farm income by fixing commodity prices at levels well above world markets, but the social and environmental impacts of these policies are visible today (ibidem). An increasing number of policy-makers, practitioners and researches are asking for Common Food Policy for the European Union: a policy setting a direction of travel for the whole food system, bringing together the various sectoral policies that affect food production, processing, distribution, and consumption, and refocusing all actions on the transition to sustainability. In this context, AFN can represent a strategic element: favoring fresh production compared to the transformed one (Marino et al., 2018) and proposing a personal communication between farmers and consumers, involving civil society and stimulating interaction among consumers, they reinforce the process of construction of sustainable consumption styles (Galli and Brunori, 2017). Such networks are able to promote a profound change in the food scenario because, through the creation of a local food system, they enhance the role of small farmers who use environmentally friendly methods and facilitate the construction of a more direct relationship between them and consumers (especially urban) (Matacena, 2016). Environmental sustainability is a theme that has reached a remarkable level of maturity-both in terms of knowledge diffusion and in the sense of practices. We have deemed significant that the environmental indicators that take the greatest value are those concerning problems of great impact on the actual debate such as the loss of genetic diversity and the use of packaging for agro-food products. This result, in line with the farms' expectations and environmental impacts, generally allows to plan policies-agricultural, food, and environmental-in support of the AFN. The differentiation of the values of the indicators among the different forms of the AFN leads the way to local policies, place-based, for the sustainability of food systems. A similar argument can be made for economic sustainability. The indicator with the highest value 
is related to the ability of the AFN to diversify sales channels, confirming the producers' increasing difficulty to adopt mono-directional strategies, traditionally represented by the sale in large-scale retail trade, favoring a differentiation of markets and, consequently, a reduction of economic risks. In this sense, the policies addressed to food systems should take into account the distribution of dynamics and distribution of power within the entire supply chain, and in particular in the very first steps of the agro-food product once it has passed the gates of the farm. AFNs can represent valid and sustainable income integration strategies, as they allow farmers and producers to keep a higher percentage of the product added value (Henke, Salvioni, 2010). Finally, with regard to the general domain of social sustainability, despite the results showing slightly lower values than the environmental and economic ones, two interesting evidences emerge: (1) the considerable importance attributed to the information of the features of the products and (2) the increase in work involvement following participation in the AFN. In this sense, the results tell us that the AFN are able to activate a greater involvement among producers, rising up their loyalty with respect to a sustainable way of doing agriculture, thanks also to the exchange of information and the producer-consumer and producer-producer feedbacks which are activated in social and community moments of marketing. In this study, for the analysis of sustainability indexes, we referred to a framework of our creation based on the FAO's SAFA approach. It should be noted that, as mentioned in paragraph 2 of the "Methodology" section, it was not possible to obtain a sustainability index in terms of governance, due to the original approach of the questionnaire that did not allow to obtain such information. For a more complete assessment of sustainability as a whole, subsequent research developments should consider this pillar, which makes up the general framework of food systems by investigating the role of regulation, process transparency, accountability, and community involvement. Furthermore, aspects of governance should require a different level of analysis, involving not only farms and producers but also institutions, food movements, associations, and networks. However, considering the wide number of researches that already exists about governance aspects of Alternative Food Networks, the authors do not retain that this missing pillar affects the validity of the framework and of the implications in terms of policies.

\section{Supplementary information}

Supplementary information accompanies this paper at https://doi.org/10.1186/s40100-019-0142-8.

Additional file 1. Complete list of themes, sub-themes, targets, and indicators.

\footnotetext{
Abbreviations

AFN: Alternative Food Networks. The acronym refers to the marketing of agricultural products through direct contact between producers and consumers. They are based on strategies alternative to those of traditional chains, and which involve a different economic dimension of the food chains and the construction of a different place-based agro-food system.; GSI: Global Sustainability Index. It is a synthetic index, built by the authors, which immediately reflect the three levels of sustainability for AFNs' farms and producers, offering a quantitative and reliable output; SPG: Solidarity purchasing group. These groups are usually set up by a number of consumers who cooperate in order to buy food and other commonly used goods directly from producers or from big retailers at a price that is fair to both parties; FM: Farmers' market. Markets where producers can sell their own products directly to the consumers; DS: Direct selling. Activities related to the selling of agricultural products by the farmer, directly within the farm or in dedicate spaces, such as farmers' markets; SAFA: Sustainability Assessment of Food and Agriculture. The program is an internationally recognized holistic global framework for the assessment of sustainability along food and agriculture value chains; FAO: Food and Agriculture Organization. It is a specialized agency of the United Nations that leads international efforts to defeat hunger; UAA: Utilized Agricultural Area. The total area taken up by arable land, permanent grassland, permanent crops, and kitchen gardens used by the holding, regardless of the type of tenure or of whether it is used as a part of common land
} 


\section{Acknowledgements}

Not applicable

\section{Authors' contributions}

LM has set the research framework, contributed to the statistical section, and reported and analyzed the results (paragraphs: $1 ; 2.1 ; 2.3 ; 3 ; 3.1 ; 3.2 ; 3.3 ; 4)$; DM has devised the methodological approach and has provided the background literature on Alternative Food Networks (paragraphs: $1 ; 2.1 ; 2.2 ; 4)$; VG contributed to the introductory part and to the "Results and discussion" section (paragraphs: 1; 3; 4); AG worked on the multivariate statistical analysis (paragraphs: 2.3; 3); MP worked on the construction of the Global Sustainability Index, on some parts of the conclusion and on the bibliography (paragraphs: 1; 2.2; 4; References); GM worked on the construction of the Global Sustainability Index, on the results and discussions, on the conclusions, and on the general review of the article (paragraphs: $1 ; 2.2$; 3.1; 3.2; 3.3; 4; References). All authors read and approved the final manuscript.

\section{Funding}

The research is based on the results of a survey, conducted in 5 Italian cities, that have been financed with resources from Department of Biosciences and Territory of the University of Molise. Prof. Davide Marino is the responsible of the cited resources.

\section{Availability of data and materials}

All data generated or analyzed during this study are included in this published article and its supplementary information files.

\section{Ethics approval and consent to participate}

The authors declare that the content of the manuscript has not been published, or submitted for publication elsewhere.

\section{Consent for publication}

All the authors declare they have approved the submitted manuscript and they consent for publication.

\section{Competing interests}

The authors declare that they have no competing interests.

\section{Author details}

${ }^{1}$ Department of Economics, University of Molise, Via de Sanctis nn, 86100 Campobasso, Italy. ${ }^{2}$ Department of Biosciences and Territory, University of Molise, Contrada Fonte Lappone 8, 86090 Pesche, Italy. ${ }^{3}$ Rome, Italy.

Received: 8 March 2019 Accepted: 16 October 2019

Published online: 29 November 2019

\section{References}

Aguglia L, De Santis F, Salvioni C (2009) Direct selling: a marketing strategy to shorten distances between production and consumption. Paper presented at the 113th EAAE Seminar, Chania, Crete, Greece, 3-6 September 2009.

Aubry C, Kebir L, Pasquier C (2008) Short Supply Chains in Periurban Zones: a way to maintain rurality near the city? Some examples taken in the lle de France Region. Paper presented at the Conference Rurality Near the City, Leuven, 7-8 February 2008.

Barbera F, Dagnes J (2016) Building alternatives from the bottom-up: the case of alternative food networks. Agric Agric Sci Procedia 8:324-331

Barilla (2014) Buono per Te, Buono per il Pianeta. Rapporto globale www.barillagroup.com.

Barry C (2012) Un producteur sur cinq vend en circuit court. Agreste Primeur vol 275

Blasi E, Cicatiello C, Pancino B, Franco S (2015) Alternative food chains as a way to embed mountaing agriculture in the urban market: the case of Trentino. Agric Food Econ 3:3. https://doi.org/10.1186/s40100-014-0023-0

Born B, Purcell M (2006) Avoiding the local trap. Scale and food systems in planning research. J Planning Educ Res 26(2):195-207

Brown C, Miller S (2008) The impacts of local market: a review of research on farmers' market an community supported agriculture (CSA). Am J Agric Econ 90(5):1298-1302

Brunori G, Galli F, Barjolle D, van Broekhuizen R, Colombo L, Giampietro M, Kirwan J, Lang T, Mathijs E, Maye D, de Roest K, Rougoor C, Schwarz J, Schmitt E, Smith J, Stojanovic Z, Tisenkopfs T, Touzard J (2016) Are local food chains more sustainable than global food chains? Considerations for assessment. Sustainability 8(5):449. https://doi.org/10.3390/ su8050449

Cavallo A, Di Donato B, Guadagno R, Marino D (2015) Cities, agriculture and changing landscapes in urban milieu: the case of Rome. Rivista di studi sulla sostenibilità, FrancoAngeli Editore, vol. 2015(1):79-97

Cicatiello C, Franco S (2012) Filiere corte e sostenibilità: una rassegna degli impatti ambientali, sociali ed economici. QA 3:47-65

Dansero E, Puttilli M (2014) Multiple territorialities of alternative food networks: six cases from Piedmont, Italy. Local Environment: The International Journal of Justice and Sustainability, 19:(6)626-643. doi: https://doi.org/10.1080/13549839. 2013.836163.

DEFRA (2005) Validity of food miles as an indicator of sustainable development: final report. AEA Technology Environment.

Van der Ploeg (2009) I nuovi contadini. Le campagne e le risposte alla globalizzazione. Donzelli Editore, Roma. ISBN: 9788860364165

Diamantini C (2016) Peri-urban agriculture as key driver to sustainability. A planning project in an Alpine city. City, Territory and. Architecture 3:15. https://doi.org/10.1186/s40410-016-0044-y 
Duncan J, Pascucci S (2017) Mapping the organisational forms of networks of alternative food networks: implications for transition. Sociologia Ruralis 57(3)

Enjolras G, Aubert M (2018) Short food supply chains and the issue of sustainability: a case study of French fruit producers. Int J Retail Distribution Manag 46(2):194-209

Fabbrizzi S, Menghini S, Marinelli N (2014) The short food supply chain: a concrete example of sustainability. A Literature Review. Rivista di Studi sulla sostenibilità 2:189-206. https://doi.org/10.3280/RISS2014-002012

Feenstra GW (2002) Creating space for sustainable food systems: lessons from the field. Agriculture and Human Values 19(2): 99-106

Food and Agriculture Organization of the United Nations (FAO) (2014) SAFA. Sustainability Assessment of Food and Agriculture Systems, Guidelines Version 3.0. Food and Agriculture Organization of the United Nations (FAO), Rome. ISBN: 978-92-5-108485-4.

Franco S, Marino D (eds) (2012) II mercato della Filiera corta. I farmers' market come luogo di incontro di produttori e consumatori, Gruppo 2013 Working Paper n.19.

Galli F, Bartolini F, Brunori G, Colombo L, Gava O, Grando S, Marescotti A (2015) Sustainability assessment of food supply chains: an application to local and global bread in Italy. Agric Food Econ 3:21

Galli F, Brunori G (2013) Short food supply chains as drivers of sustainable development. Evidence Document. Document developed in the framework of the FP7 project FOODLINKS (GA No. 265287). Laboratorio di studi rurali Sismondi, Pisa. ISBN978-88-90896-01-9.

Galli F, Brunori G (2017) Sustainability performance of food chains: linking biodiversity and nutritional value in Italian wheatto-bread chains. Adv Food Security Sustainability 2:137-163

Gaviglio A, Bertocchi M, Marescotti MA, Demartini E, Pirani A (2016) The social pillar of sustainability: a quantitative approach at the farm level. Agric Food Econ 4:15

Giaré F, Giuca S (2012) Agricoltori e filiera corta. Profili giuridici e dinamiche socio-economiche. INEA, Roma

Gibson R (2006) Beyond the pillars: sustainability assessment as a framework for effective integration of social, economic and ecological considerations in significant decision-making. J Environ Assessment Policy Manag 8(3):259-280

Global Reporting Initiative (GRI) (2011) Sustainability Reporting Guidelines. www.globalreporting.org.

Goodman D (2003) The quality turn and alternative food practices: reflections and agenda. J Rural Studies 19:1-7

Hardesty S, Leff P (2010) Determining marketing costs and returns in alternative marketing channels. Renewable Agric Food Syst 25(1):24-34. https://doi.org/10.1017/S1742170509990196

Henke R, Salvioni C (2010) Diffusione, struttura e redditività delle aziende multifunzionali (Dissemination, structure and profitability of multi-functional farms - in Italian.) In: Agriregionieuropa, Vol. 6(20), pp. 16-19. Available at: https:// agriregionieuropa.univpm.it/, DoA: 21.11.2017.

Henke R, Vanni F (2017) Peri-urban agriculture: an analysis of farm typologies in Italy. New Medit 3:11-18

Higgins V, Dibden J, Cocklin C (2008) Building alternative agri-food networks: certification, embeddedness and agrienvironmental governance. J Rural Studies 24(1):15-27

HLPE (2017) Nutrition and food systems. A report by the High Level Panel of Experts on Food Security and Nutrition of the Committee on World Food Security, Rome

Holloway L, Kneafsey M, Venn L, Cox R, Dowler E, Tuomainen H (2007) Possible food economies: a methodological framework for exploring food production-consumption relationships. Sociologia Ruralis 47(1):1-19

Ilbery B, Maye D (2005) Food supply chains and sustainability: evidence from specialist food producers in the Scottish-English Borders. Land Use Policy 22(4):331-344

IPES-Food (2019) Towards a Common Food Policy for the European Union. International Panel of Experts on Sustainable Food Systems, Report.

Kneafsey M, Venn L, Schmutz U, Balázs B, Trenchard L, Eyden-Wood T, Bos E, Sutton G, Blackett M (2013) Short food supply chains and local food systems in the EU. A State of Play of their Socio-Economic Characteristics. European Commission. doi:https://doi.org/10.2791/88784

Lamine C (2014) Sustainability and resilience in agrifood systems: reconnecting agriculture, food and the environment. Sociologia Ruralis 55(1):41-61

Lyon P, Viv C, Kvarnbrink E, Colquhoun A (2009) Shopping at the farmers' market: consumers and their perspectives. Foodservice 20(1):21-30

Marino D (ed) (2016) Agricoltura urbana e filiere corte: un quadro della realtà italiana. FrancoAngeli, Roma. ISBN:978-88-917-4378-7.

Marino D, Mastronardi L, Giannelli A, Giaccio V, Mazzocchi G (2018) Territorialisation dynamics for Italian farms adhering to Alternative Food Networks. In: Dymitrow M, Halfacree K (eds) Bulletin of Geography. Socio-economic Series, No. 40 (in press). doi: https://doi.org/10.2478/bog-2018-0018.

Mastronardi L, Giannelli A (2016) La sostenibilità dell'agricoltura periurbana: un'analisi sulle imprese della filiera corta. Agriregionieuropa anno 12 n. 44.

Mastronardi L, Marino D, Cavallo A, Giannelli A (2015) Exploring the role of farmers in short food supply chains: the case of Italy. Int Food Agribusiness Manag Rev 18(2):109-130

Matacena R (2016) Linking alternative food networks and urban food policy: a step forward in the transition towards a sustainable and equitable food system? Int Rev Social Res 6(1):49-58

Penker M (2006) Mapping and measuring the ecological embeddedness of food supply chains. Geoforum 37(3):368-379

Peters R (ed) (2012) Local food and short supply chains. European Commission - European Network for Rural Development, Belgium

Raffaelli R, Coser L, Gios G (2009) Esperienze di filiera corta nell'agro-alimentare: un'indagine esplorativa in provincia di Trento. Economia agro-alimentare $\mathrm{n} .1$

Renting H, Marsden T, Banks J (2003) Understanding alternative food networks: exploring the role of short food supply chains in rural development. Environ Planning A 35(3):393-411

Sini M.P. (2009) Aspetti del dibattito sulla filiera corta. Agriregionieuropa anno 5 n.16.

Sustain (2002) Local food: benefits, obstacles and opportunities. Sustain: The alliance for better farming and food, London

Torquati B, Giacché G, Musotti F, Taglione C (2009) Agricoltura periurbana tra adattamento aziendale, funzioni riconosciute e funzioni percepite. Rivista di Economia Agraria anno LXIV 3-4:401-441 
Tregear A (2011) Progressing knowledge in alternative and local food networks: Critical reflections and a research agenda. Journal of Rural Studies 27(4):419-430. https://doi.org/10.1016/j.jrurstud.2011.06.003

Tropp D (2008) The growing role of local food markets: discussion. Am J Agric Econ 90(5):1310-1311. https://doi.org/10.1111/ j.1467-8276.2008.01222.x

UN DPSCD (1996) Indicators of sustainable development: framework and methodologies, Division for Sustainable Development. Department for Policy Co-ordination and Sustainable Development, New York

Venn L, Kneafsey M, Holloway L, Cox R, Dowler E, Tuomainen H (2006) Researching European alternative food networks: some methodological considerations. Area 38(3):248-258

Watts D, Ilbery B, Maye D (2005) Making reconnections in agro-food geography: alternative systems of food provision. Progress Human Geography 29(1):22-40

Whatmore S, Stassart P, Renting H (2003) Guest editorial: what's alternative about alternative food networks? Environ Planning A 35:389-391

Wiese A, Kellner J, Lietke B, Toporowski W, Zielke S (2012) Sustainability in retailing - a summarative content analysis. Int J Retail Distribution Manag 40(4):318-335

Wiese A, Zielke S, Toporowski W (2015) Sustainability in retailing - research streams and emerging trends. International Journal of Retail \& Distribution Management 43(4/5). https://doi.org/10.1108/IJRDM-02-2015-0024

Zezza A (2013) Misurare lo sviluppo sostenibile. In: Abitabile C, Arzeni A (eds) Misurare la sostenibilità dell'agricoltura biologica. INEA, Roma

\section{Publisher's Note}

Springer Nature remains neutral with regard to jurisdictional claims in published maps and institutional affiliations.

Submit your manuscript to a SpringerOpen ${ }^{\circ}$ journal and benefit from:

- Convenient online submission

- Rigorous peer review

Open access: articles freely available online

- High visibility within the field

- Retaining the copyright to your article

Submit your next manuscript at $\boldsymbol{\nabla}$ springeropen.com 